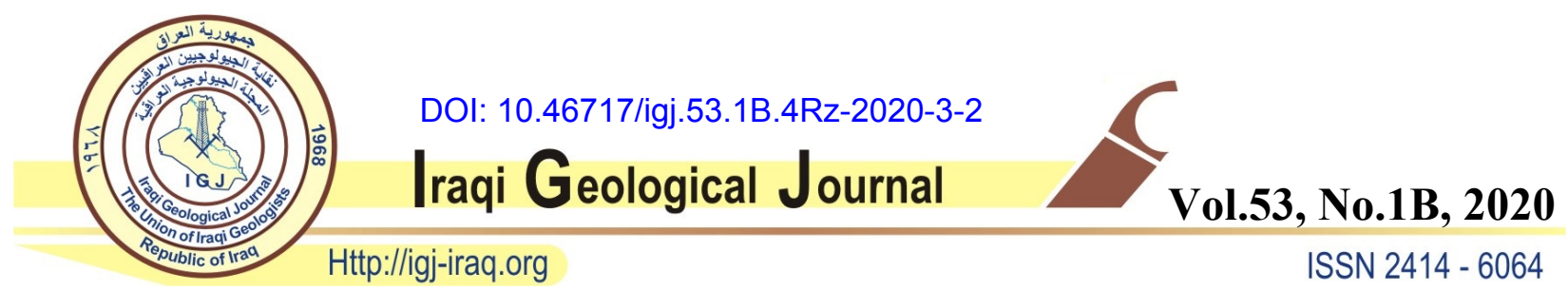

\title{
THE USAGE OF GIS FOR THE DEVASTATED URBAN CENTERS MANAGEMENT AND PRESERVATION OF MONUMENTS/ CASE STUDY: NABI-JARJIS DISTRICT IN MOSUL CITY IN IRAQ
}

${ }^{1}$ Kossay K. Al-Ahmady and ${ }^{2}$ Sarah D. Al-Jarjees"

${ }^{1}$ University of Mosul, Mosul, Iraq

${ }^{2}$ College of Environmental Science and Technology, University of Mosul, Mosul, Iraq

*E-mail: saradurgham@uomosul.edu.iq

Received: 3 November 2019; accepted: 20 December 2019

\begin{abstract}
After the liberation of Mosul in July 2017, wide areas in Mosul city have experienced large scale deterioration; especially in the right bank of the city, and Nabi-Jarjis district (where Alhadba Minaret and Nabi-Jarjis mosque located) appears to be one of the most affected parts in the City. In the current study, the debris of the Nabi-Jarjis district was studied in detail by finding the destroyed areas using GIS, then, by utilizing ArcGIS network analyst extension, the optimal route for collecting the debris from the Nabi-Jarjis district was found, considering archaeological sites as barriers. The proposed collection system focuses on reducing the time taken in the collection process and the distance traveled to reduce the economic and environmental costs of the proposed collection system. The results showed that the destruction was about $71.01 \%$ of the Nabi-Jarjis district total area, and according to land use, the residential buildings area accounted for about $81.99 \%$ of the total area that means remaining less than $10 \%$ habitable places in the region. Finally, as a final result of the current study, an optimal route for debris removal was given in a table that gives detailed information about the proposed route. Keyword: Geographic information systems (GIS); Disaster waste management; Debris collection; optimal route; Nabi-Jarjis district in Mosul
\end{abstract}




\section{INTRODUCTION}

Mosul city has experienced large-scale deterioration after its liberation due to the severe damage that occurs to its infrastructure, urban fabric and cultural heritage (UNEP, 2018). Due to its densely constructed nature (Altuhafi et al., 2013), the Nabi-Jarjis district (where Alhadbaa Minaret and Nabi-Jarjis mosque located) appears to be one of the most affected parts of the Mosul Old City. The Nabi-Jarjis Mosque is one of the Mosul Heritage Archaeological Mosques (Khoury, 2002). It is located in Al-Shaarin market on Nineveh Street near the markets of Sarj Khaneh. The mosque was built in the era of the Ottoman Empire in $1208 \mathrm{AH}$, with an estimated area of 2000 square meters (Khoury, 2002), it was re-maintained in 2009, however, it had been destroyed on July 2014. Another prestigious monument in the Nabi-Jarjis district is Alhadbaa Minaret, it is considered as one of the most important monuments in the city of Mosul dated back to $1172 \mathrm{AD}$ and its location forms a focus in the oldest part of the Mosul old city (Greswell, 1997). Recently, the Minaret was almost destroyed, and according to that there are many efforts to rebuild the Minaret (Mosul Municipality, 2018), therefore the major requirement is to collect and isolate its debris that may spread in its nearby vicinity because it may be used in the Minaret rehabilitation and to prevent this debris to be removed with other nearby debris. According to this, the Minaret surrounding area has been chosen as a model for the debris removal planning process using the network analysis technique within GIS to preserve this historical and cultural landmark.

The need to remove the huge amounts of generated debris and preserving Alhadbaa Minaret ruins at the same time highlighted the importance of developing an appropriate and efficient management system for appropriate removal of the debris from Nabi-Jarjis region. Debris removing strategies differ from one country to another (Al-Ahmady and Jasim, 2019). The quantity and distribution of this debris, available equipment to remove them differs from one country to another, as well as human and financial resources, which leaves a wide range of options for the debris removing strategies (Asari et al., 2013).

There are several algorithm solutions introduced by GIS technology that uses standard metrology (i.e. path length) to determine the optimal route for a particular destination (Parker, 2007). The use of this technology in waste collection and transportation can provide economic and environmental benefits by reducing accumulated time, traveled distance, fuel consumption and emission of pollutant gases (Chalkias and Lasaridi, 2009). The optimal route has been identified using GIS in many previous studies and research (Ansari et al., 2015). 


\section{AIM OF STUDY}

Current study aimed to calculate the destroyed area in the Nabi-Jarjis district in the right bank of Mosul, and then produce optimized route for trucks for debris removal from the study area to reduce travelled distance, collection time, and total collection costs, with focuses on preserving Alhadbaa Minaret ruins from being mixed with other debris due to its historical and cultural value, so it could be used in the Minaret rehabilitation.

\section{STUDY AREA}

The Nabi-Jarjis district is located within the old city in the right bank of Mosul city in Iraq, according to digital maps produced by GIS, the Nabi-Jarjis district is about 0.252 square kilometers in area and located at the $43^{\circ} 7^{\prime} 31.668^{\prime \prime}$ East longitude and $36^{\circ} 20^{\prime} 41.596^{\prime \prime}$ North latitude (38S 3317824023833 UTM). Its pre-conflict population is over 7620 people within 1320 housing units (UNEP, 2017). The importance of this district refers to the presence of Alhadbaa Minaret which is considered one of the most important monuments in the city of Mosul, and its location forms a focus in the oldest part of the Mosul old city (Mahmood, 2015).

\section{METHODOLOGY}

\section{Acquisition Data}

Satellite images of the Old City are gathered from WorldView-2 satellite. The satellite multispectral images of the Old City in the years 2014 and 2017 of $0.5 \mathrm{~m}$ resolution is used. Raster images, maps input and processing conducted using ArcGIS network analyst extension.

\section{Analysis of Satellite Image Data and Calculation of Destroyed Areas}

Using satellite images, the destroyed areas in the Nabi-Jarjis district were identified using GIS by conducting a change detection process for two space images, the first was taken on 17/7/2014 (Fig. 1a) and the other on 18/7/2017 (Fig. 1b). The second was subtracted from the first one to distinguish changes between the two dates, Then, using the Arc map software the destroyed sites were identified by digitizing process using the Arc map software as shown in Figure (2), and the total destroyed area was calculated. 


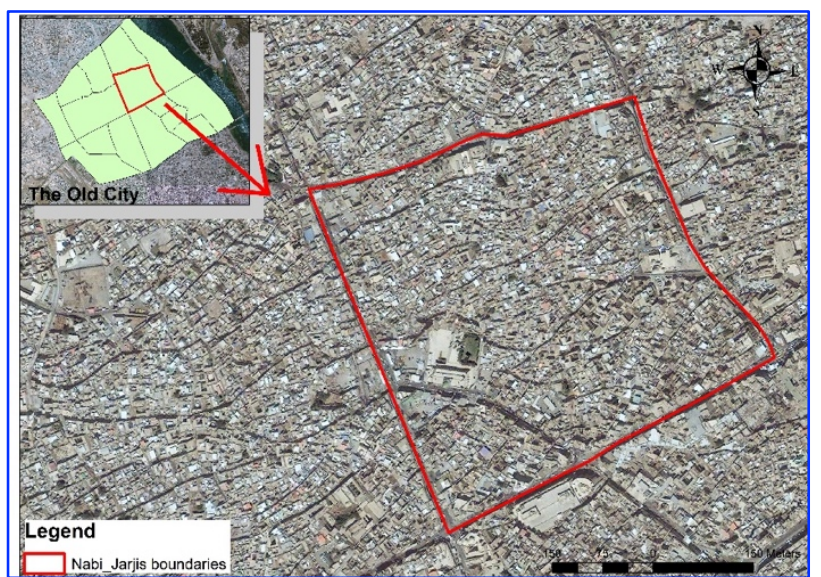

Fig. 1: (a) Satellite image, date 17/7/2014

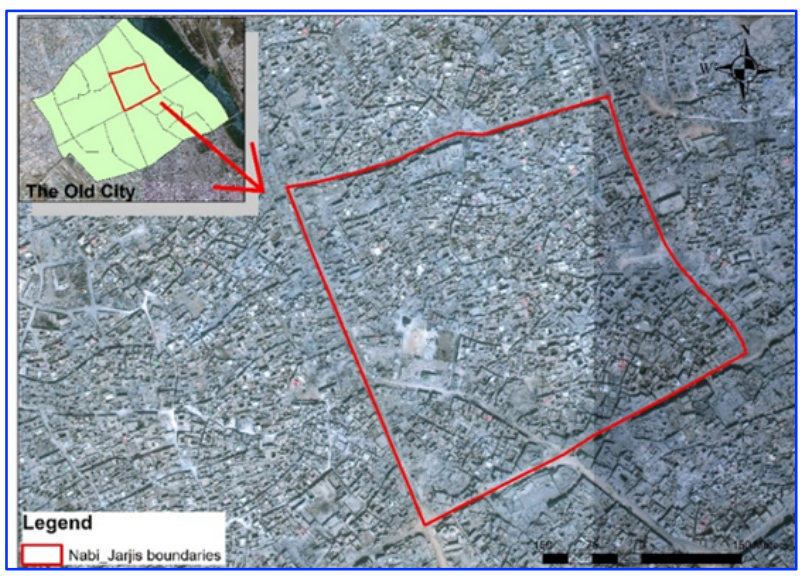

Fig. 1: (b): Satellite image, date 18/7/2017

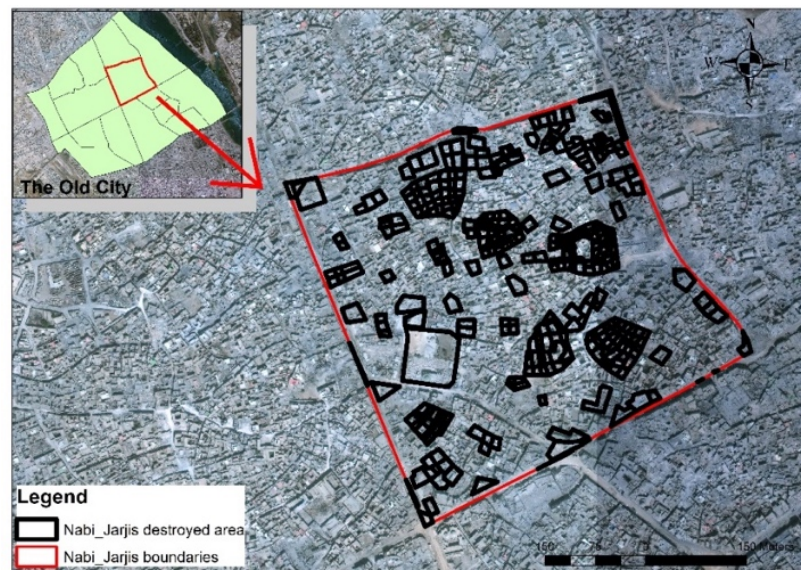

Fig. 2: Destroyed sites in the Nabi-Jarjis district 
The percentage of destroyed areas was determined by applying the following equation:

Percentage $=($ Destroyed Area $/$ Total Area $) * 100 \%$

Then, crossing the destroyed areas` data with the land use layer using GIS gives results according to land use (residential, commercial, industrial, other uses), results were fixed in a table that will appear later in the results section.

\section{The Optimal Route for Debris Removal}

In the current study, Esri's Arc GIS Desktop version 10.4.1 with Network Analysis (NA) extension and Route solver was used in order to perform the optimal route determination process.

There were several inputs to the ArcGIS Network Analyst route solver to calculate the optimal route for debris removal. At first, the road network in the Nabi-Jarjis district was initially drawn from the satellite image taken on 17/7/2014 (Fig. 3) and the data was modified based on another taken on 18/7/2017 (due to the large deterioration in the Roads network after the liberation). Then, a network dataset of the Nabi-Jarjis district was constructed to ensure all street segments are connected at junctions. A layer for debris piles locations (Fig. 4) and other for archaeological sites -considered as barriers- (Fig. 5) were then added. The starting point for the debris collection route is located near the main street cause the route is preferred to start and end near the main road using physical and topographical barriers (O'leary et al., 2002). Distance and time parameters were determined as meter for distance unit and minute for time, the vehicle used to collect debris is assumed to be a large truck of 18 tons which is currently available for Mosul Municipality, the program was given solve order, after several minutes, the optimal route for removing debris from the Nabi-Jarjis district was done.

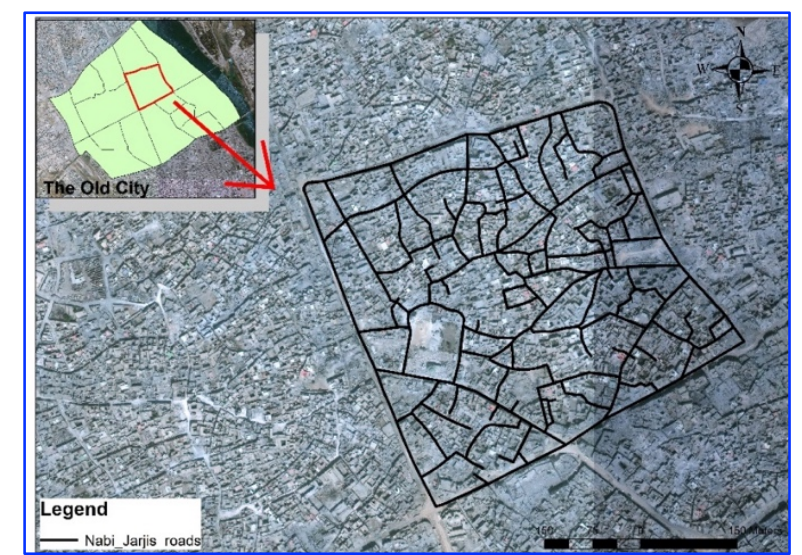

Fig. 3: Road network in the Nabi-Jarjis district 


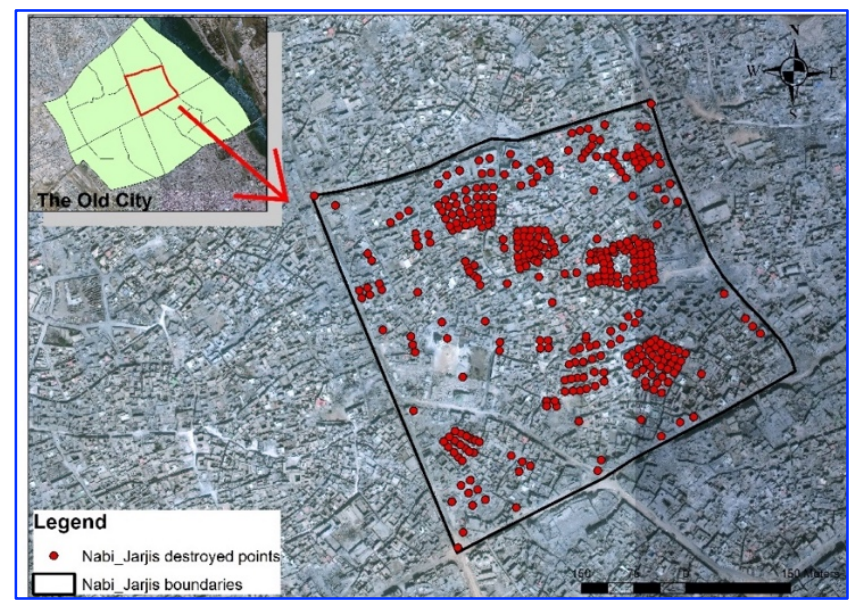

Fig. 4: Debris piles locations

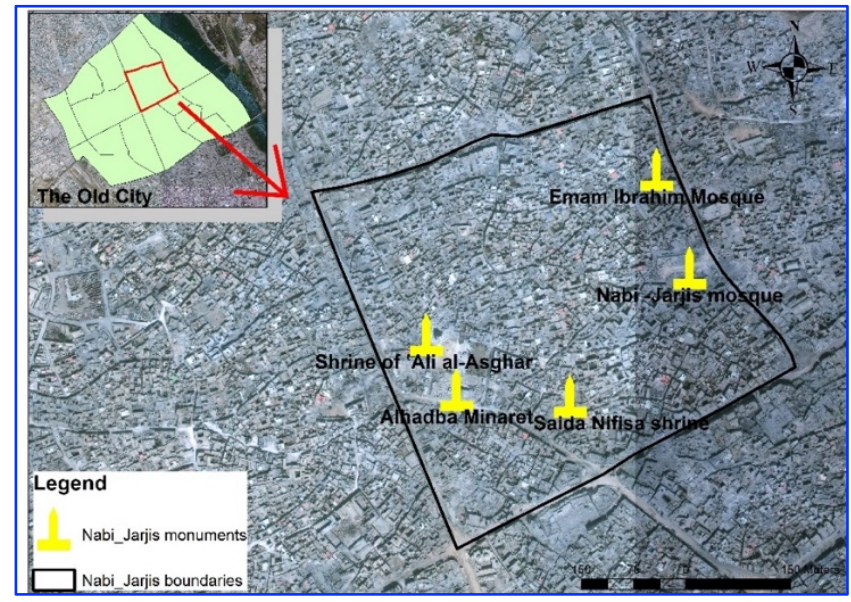

Fig. 5: Archaeological sites in the Nabi-Jarjis district

\section{RESULTS AND DISCUSSION}

\section{Destroyed Areas}

By analyzing the satellite images of the Nabi-Jarjis district, the destroyed areas were identified and calculated in square meters (Fig. 6).

It is clear from the Fig. 6 that wide areas in the Nabi-Jarjis district have been subjected to severe damage, and this is agreed with the report of the United Nations Environment Program (UNEP, 2017), where the report states that wide areas in the right bank of Mosul was heavily destroyed, and the most destruction is located in the old city regions (where Nabi-Jarjis district located) due to the dense fabric of this part of the city. Table 1 gives detailed information about destroyed areas in the Nabi-Jarjis district obtained from GIS analysis. The field survey revealed 
that the most affected areas were the residential buildings (Figs. $7 \& 8$ ) show the destruction that happened to the region.

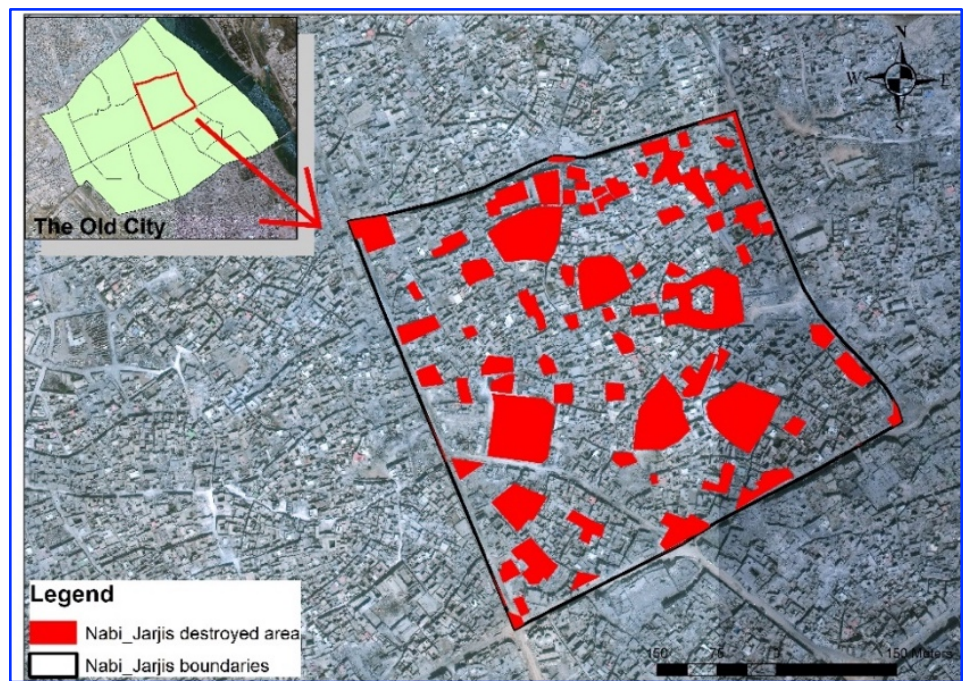

Fig. 6: The destroyed areas in Nabi-Jarjis district

Table 1: Destroyed areas in the Nabi-Jarjis district

\begin{tabular}{|c|c|c|c|c|c|}
\hline \multirow[b]{2}{*}{$\begin{array}{c}\text { Total area } \\
\qquad\left(\mathrm{m}^{2}\right)\end{array}$} & \multirow[b]{2}{*}{$\begin{array}{c}\text { Destroyed } \\
\text { area }\left(\mathrm{m}^{2}\right)\end{array}$} & \multirow[b]{2}{*}{$\begin{array}{c}\% \\
\text { destroyed }\end{array}$} & \multicolumn{3}{|c|}{ Destroyed Area in $\mathrm{m}^{2}$ according to land use } \\
\hline & & & Residential & $\begin{array}{c}\text { Commercial and } \\
\text { industrial }\end{array}$ & Other uses \\
\hline 252934.77 & 179608.98 & 71.01 & 147279.36 & 6142.19 & 19422.9 \\
\hline
\end{tabular}

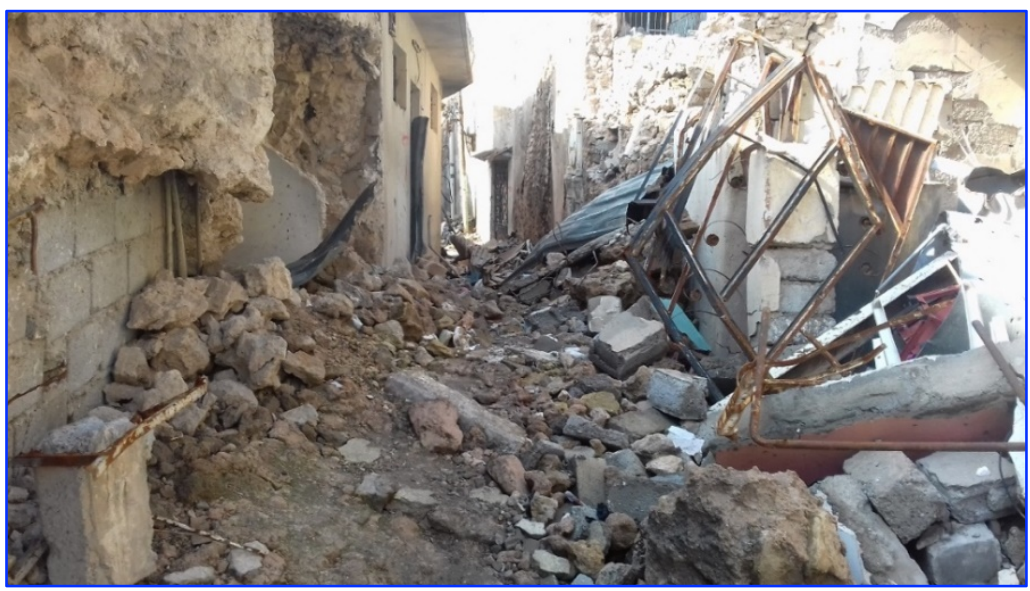

Fig. 7: The destroyed residential area near Alhadba Minaret 


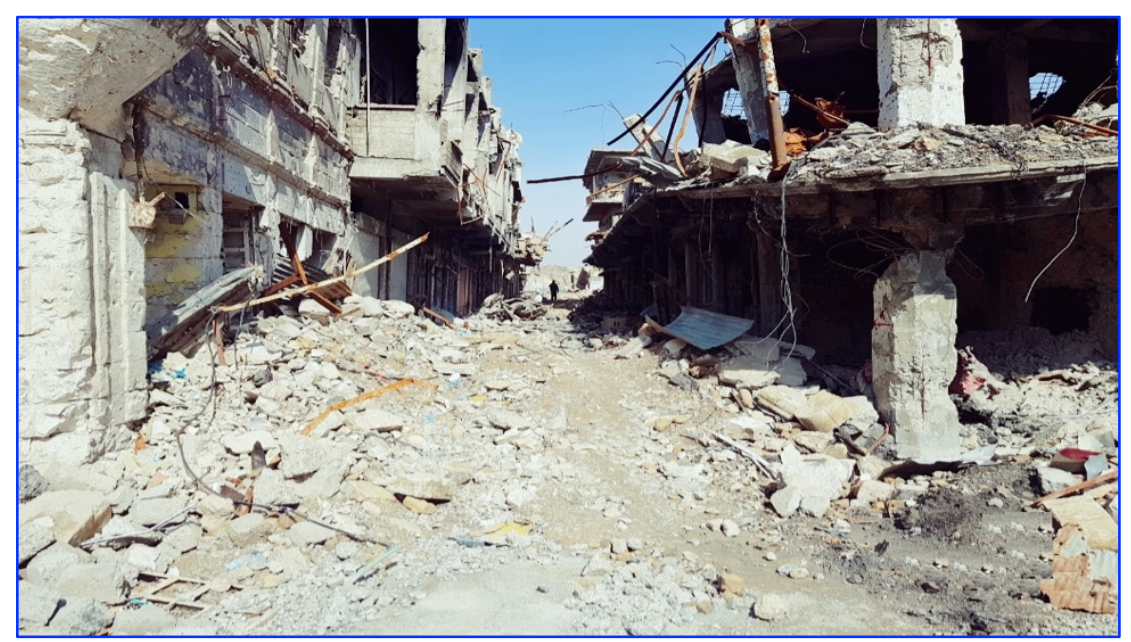

Fig. 8: The destroyed commercial area near Alhadba Minaret

\section{Optimal Route for Debris Removal}

Most of the alleys in the Nabi-Jarjis district are narrow and small, therefore the process of debris removal takes several steps. Initially, small machines with labor force are used to transport the rubbles to places where large machines can reach, then rubbles is transferred to the temporary station where initial sorting is done, the remaining rubbles-which cannot be isolated-is transferred to the last destination which represents landfill site outside the city of Mosul. In the present study, the optimal route for debris removal from the affected areas was identified, Figure (9) illustrates the proposed route for the Nabi-Jarjis district.

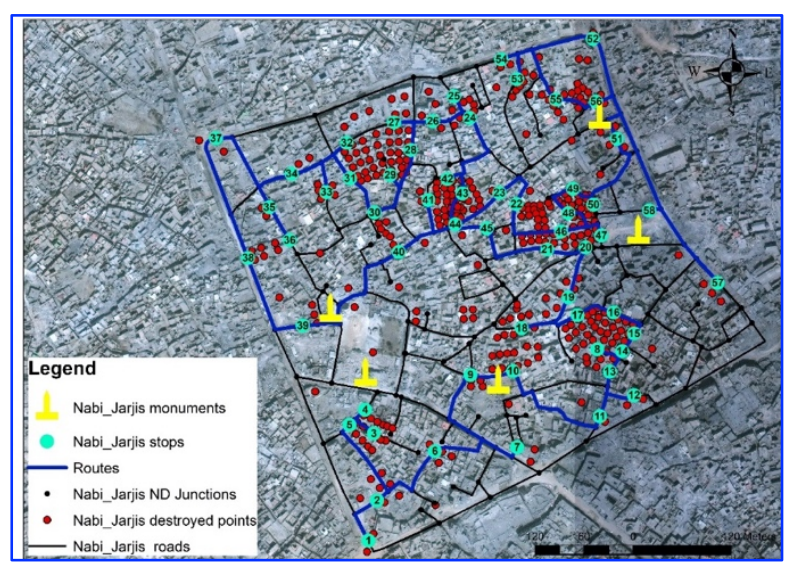

Fig. 9: The optimal route for debris removal

As shown in Figure (9), the suggested route of the Nabi-Jarjis is as near as possible to the rubbles piles and follows the shortest route of undestroyed usable roads. Many of the roads inside the area 
are currently out of service, part of which are currently maintained while others still damaged, so choosing a specific route for debris removal allows this process to be carried out concurrently with road maintenance. Because the roads in the study area may still not completely cleared of unexploded ordnance, therefore, the proposed route reduces the distance traveled and thus reduces the probability of accidents. Table 3 gives detailed information about the proposed debris removal route for the Nabi-Jarjis district. In table 3, the sequence field illustrated the order of the debris collection points to be passed by the vehicle that used for removing debris (table 2 illustrates coordinates for each stop point), arrive curb approach and the depart curb approach in table 3 gives the sidewalk location for route directions from the starting point until reaching the end point, (side of edge) gives the direction of the vehicle movements on the road network and any change between left and right means there is a turning point. (curb approach) gives the position of lifting debris for the vehicle, here (either side of vehicle) means that the debris is collected from both sides of the route, where the (cumulative distance) gives the total distance of the route-measured in metersfrom the start till reaching the end. According to the Table 3, the total distance of the proposed route is 4959.69 meters, and the total time required for debris collection from the study area in each trip is 621.84 seconds. 
Table 2: The stops coordinates

\begin{tabular}{|c|c|c|}
\hline stops & Latitude & Longitude \\
\hline 1 & $36^{\circ} 20^{\prime} 27.284^{\prime \prime} \mathrm{N}$ & $43^{\circ} 7^{\prime} 36.573^{\prime \prime} \mathrm{E}$ \\
\hline 2 & $36^{\circ} 20^{\prime} 28.883^{\prime \prime} \mathrm{N}$ & $43^{\circ} 7^{\prime} 36.954^{\prime \prime} \mathrm{E}$ \\
\hline 3 & $36^{\circ} 20^{\prime} 31.864^{\prime \prime} \mathrm{N}$ & $43^{\circ} 7^{\prime} 35.527^{\prime \prime} \mathrm{E}$ \\
\hline 4 & $36^{\circ} 20^{\prime} 31.543^{\prime \prime} \mathrm{N}$ & $43^{\circ} 7^{\prime} 36.729^{\prime \prime} \mathrm{E}$ \\
\hline 5 & $36^{\circ} 20^{\prime} 32.476^{\prime \prime} \mathrm{N}$ & $43^{\circ} 7^{\prime} 36.287^{\prime \prime} \mathrm{E}$ \\
\hline 6 & $36^{\circ} 20^{\prime} 30.885^{\prime \prime} \mathrm{N}$ & $43^{\circ} 7^{\prime} 39.747^{\prime \prime} \mathrm{E}$ \\
\hline 8 & $36^{\circ} 20^{\prime} 31.105^{\prime \prime} \mathrm{N}$ & $43^{\circ} 7^{\prime} 43.776^{\prime \prime} \mathrm{E}$ \\
\hline 9 & $36^{\circ} 20^{\prime} 32.396^{\prime \prime} \mathrm{N}$ & $43^{\circ} 7^{\prime} 47.812^{\prime \prime} \mathrm{E}$ \\
\hline 10 & $36^{\circ} 20^{\prime} 33.257^{\prime \prime} \mathrm{N}$ & $43^{\circ} 7^{\prime} 49.470^{\prime \prime} \mathrm{E}$ \\
\hline 11 & $36^{\circ} 20^{\prime} 37.785^{\prime \prime} \mathrm{N}$ & $43^{\circ} 7^{\prime} 53.461^{\prime \prime} \mathrm{E}$ \\
\hline 12 & $36^{\circ} 20^{\prime} 34.178^{\prime \prime} \mathrm{N}$ & $43^{\circ} 7^{\prime} 48.253^{\prime \prime} \mathrm{E}$ \\
\hline 13 & $36^{\circ} 20^{\prime} 34.997^{\prime \prime} \mathrm{N}$ & $43^{\circ} 7^{\prime} 48.847^{\prime \prime} \mathrm{E}$ \\
\hline 14 & $36^{\circ} 20^{\prime} 35.711^{\prime \prime} \mathrm{N}$ & $43^{\circ} 7^{\prime} 49.411^{\prime \prime} \mathrm{E}$ \\
\hline 15 & $36^{\circ} 20^{\prime} 35.056^{\prime \prime} \mathrm{N}$ & $43^{\circ} 7^{\prime} 47.619^{\prime \prime} \mathrm{E}$ \\
\hline 16 & $36^{\circ} 20^{\prime} 36.530^{\prime \prime} \mathrm{N}$ & $43^{\circ} 7^{\prime} 48.391^{\prime \prime} \mathrm{E}$ \\
\hline 17 & $36^{\circ} 20^{\prime} 36.398^{\prime \prime} \mathrm{N}$ & $43^{\circ} 7^{\prime} 46.619^{\prime \prime} \mathrm{E}$ \\
\hline 18 & $36^{\circ} 20^{\prime} 33.941^{\prime \prime} \mathrm{N}$ & $43^{\circ} 7^{\prime} 41.416^{\prime \prime} \mathrm{E}$ \\
\hline 19 & $36^{\circ} 20^{\prime} 34.130^{\prime \prime} \mathrm{N}$ & $43^{\circ} 7^{\prime} 43.510^{\prime \prime} \mathrm{E}$ \\
\hline 20 & $36^{\circ} 20^{\prime} 35.833^{\prime \prime} \mathrm{N}$ & $43^{\circ} 7^{\prime} 43.889^{\prime \prime} \mathrm{E}$ \\
\hline 21 & $36^{\circ} 20^{\prime} 35.769^{\prime \prime} \mathrm{N}$ & $43^{\circ} 7^{\prime} 33.142^{\prime \prime} \mathrm{E}$ \\
\hline 22 & $36^{\circ} 20^{\prime} 37.096^{\prime \prime} \mathrm{N}$ & $43^{\circ} 7^{\prime} 46.150^{\prime \prime} \mathrm{E}$ \\
\hline 23 & $36^{\circ} 20^{\prime} 38.416^{\prime \prime} \mathrm{N}$ & $43^{\circ} 7^{\prime} 30.400^{\prime \prime} \mathrm{E}$ \\
\hline 24 & $36^{\circ} 20^{\prime} 39.152^{\prime \prime} \mathrm{N}$ & $43^{\circ} 7^{\prime} 32.415^{\prime \prime} \mathrm{E}$ \\
\hline 25 & $36^{\circ} 20^{\prime} 40.442^{\prime \prime} \mathrm{N}$ & $43^{\circ} 7^{\prime} 31.384^{\prime \prime} \mathrm{E}$ \\
\hline 26 & $36^{\circ} 20^{\prime} 43.142^{\prime \prime} \mathrm{N}$ & $43^{\circ} 7^{\prime} 28.705^{\prime \prime} \mathrm{E}$ \\
\hline 27 & $36^{\circ} 20^{\prime} 41.790^{\prime \prime} \mathrm{N}$ & $43^{\circ} 7^{\prime} 32.449^{\prime \prime} \mathrm{E}$ \\
\hline 28 & $36^{\circ} 20^{\prime} 41.086^{\prime \prime} \mathrm{N}$ & $43^{\circ} 7^{\prime} 34.177^{\prime \prime} \mathrm{E}$ \\
\hline 29 & $36^{\circ} 20^{\prime} 43.060^{\prime \prime} \mathrm{N}$ & $43^{\circ} 7^{\prime} 35.130^{\prime \prime} \mathrm{E}$ \\
\hline 30 & $36^{\circ} 20^{\prime} 43.905^{\prime \prime} \mathrm{N}$ & $43^{\circ} 7^{\prime} 37.434^{\prime \prime} \mathrm{E}$ \\
\hline 31 & $36^{\circ} 20^{\prime} 41.814^{\prime \prime} \mathrm{N}$ & $43^{\circ} 7^{\prime} 37.290^{\prime \prime} \mathrm{E}$ \\
\hline 32 & $36^{\circ} 20^{\prime} 40.314^{\prime \prime} \mathrm{N}$ & $43^{\circ} 7^{\prime} 36.551^{\prime \prime} \mathrm{E}$ \\
\hline 33 & $36^{\circ} 20^{\prime} 38.767^{\prime \prime} \mathrm{N}$ & $43^{\circ} 7^{\prime} 37.783^{\prime \prime} \mathrm{E}$ \\
\hline 34 & $36^{\circ} 20^{\prime} 41.653^{\prime \prime} \mathrm{N}$ & $43^{\circ} 7^{\prime} 35.325^{\prime \prime} \mathrm{E}$ \\
\hline 35 & $36^{\circ} 20^{\prime} 42.821^{\prime \prime} \mathrm{N}$ & $43^{\circ} 7^{\prime} 38.267^{\prime \prime} \mathrm{E}$ \\
\hline 36 & $36^{\circ} 20^{\prime} 40.851^{\prime \prime} \mathrm{N}$ & $43^{\circ} 7^{\prime} 39.185^{\prime \prime} \mathrm{E}$ \\
\hline 37 & $36^{\circ} 20^{\prime} 41.701^{\prime \prime} \mathrm{N}$ & $43^{\circ} 7^{\prime} 40.101^{\prime \prime} \mathrm{E}$ \\
\hline 38 & $36^{\circ} 20^{\prime} 41.139^{\prime \prime} \mathrm{N}$ & $43^{\circ} 7^{\prime} 40.857^{\prime \prime} \mathrm{E}$ \\
\hline 39 & $36^{\circ} 20^{\prime} 39.906^{\prime \prime} \mathrm{N}$ & $43^{\circ} 7^{\prime} 40.531^{\prime \prime} \mathrm{E}$ \\
\hline 40 & $36^{\circ} 20^{\prime} 41.193^{\prime \prime} \mathrm{N}$ & $43^{\circ} 7^{\prime} 42.663^{\prime \prime} \mathrm{E}$ \\
\hline 41 & $36^{\circ} 20^{\prime} 39.774^{\prime \prime} \mathrm{N}$ & $43^{\circ} 7^{\prime} 42.084^{\prime \prime} \mathrm{E}$ \\
\hline 42 & $36^{\circ} 20^{\prime} 38.985^{\prime \prime} \mathrm{N}$ & $43^{\circ} 7^{\prime} 45.072^{\prime \prime} \mathrm{E}$ \\
\hline 43 & $36^{\circ} 20^{\prime} 39.701^{\prime \prime} \mathrm{N}$ & $43^{\circ} 7^{\prime} 45.733^{\prime \prime} \mathrm{E}$ \\
\hline 44 & $36^{\circ} 20^{\prime} 40.763^{\prime \prime} \mathrm{N}$ & $43^{\circ} 7^{\prime} 43.512^{\prime \prime} \mathrm{E}$ \\
\hline 45 & $36^{\circ} 20^{\prime} 41.406^{\prime \prime} \mathrm{N}$ & $43^{\circ} 7^{\prime} 46.273^{\prime \prime} \mathrm{E}$ \\
\hline 46 & $36^{\circ} 20^{\prime} 40.437^{\prime \prime} \mathrm{N}$ & $43^{\circ} 7^{\prime} 46.070^{\prime \prime} \mathrm{E}$ \\
\hline 47 & $36^{\circ} 20^{\prime} 39.575^{\prime \prime} \mathrm{N}$ & $43^{\circ} 7^{\prime} 47.705^{\prime \prime} \mathrm{E}$ \\
\hline 48 & $36^{\circ} 20^{\prime} 39.093^{\prime \prime} \mathrm{N}$ & $43^{\circ} 7^{\prime} 46.942^{\prime \prime} \mathrm{E}$ \\
\hline 49 & $36^{\circ} 20^{\prime} 43.987^{\prime \prime} \mathrm{N}$ & $43^{\circ} 7^{\prime} 39.336^{\prime \prime} \mathrm{E}$ \\
\hline 50 & $36^{\circ} 20^{\prime} 44.995^{\prime \prime} \mathrm{N}$ & $43^{\circ} 7^{\prime} 40.345^{\prime \prime} \mathrm{E}$ \\
\hline 51 & $36^{\circ} 20^{\prime} 44.146^{\prime \prime} \mathrm{N}$ & $43^{\circ} 7^{\prime} 41.140^{\prime \prime} \mathrm{E}$ \\
\hline 52 & $36^{\circ} 20^{\prime} 46.493^{\prime \prime} \mathrm{N}$ & $43^{\circ} 7^{\prime} 42.633^{\prime \prime} \mathrm{E}$ \\
\hline 53 & $36^{\circ} 20^{\prime} 45.722^{\prime \prime} \mathrm{N}$ & $43^{\circ} 7^{\prime} 43.426^{\prime \prime} \mathrm{E}$ \\
\hline 54 & $36^{\circ} 20^{\prime} 44.943^{\prime \prime} \mathrm{N}$ & $43^{\circ} 7^{\prime} 45.349^{\prime \prime} \mathrm{E}$ \\
\hline 55 & $36^{\circ} 20^{\prime} 44.896^{\prime \prime} \mathrm{N}$ & $43^{\circ} 7^{\prime} 47.319^{\prime \prime} \mathrm{E}$ \\
\hline 56 & $36^{\circ} 20^{\prime} 43.424^{\prime \prime} \mathrm{N}$ & $43^{\circ} 7^{\prime} 48.387^{\prime \prime} \mathrm{E}$ \\
\hline 57 & $36^{\circ} 20^{\prime} 47.373^{\prime \prime} \mathrm{N}$ & $43^{\circ} 7^{\prime} 47.099^{\prime \prime} \mathrm{E}$ \\
\hline 58 & $36^{\circ} 20^{\prime} 40.796^{\prime \prime} \mathrm{N}$ & $43^{\circ} 7^{\prime} 47.288^{\prime \prime} \mathrm{E}$ \\
\hline
\end{tabular}




\section{Table 3: The proposed debris removal route information}

\begin{tabular}{|c|c|c|c|c|c|c|}
\hline Sequence & Arrive curb approach & Depart curb approach & Side of edge & Curb Approach & Cumul_Distance(m) & Cumul_Time (min \\
\hline 1 & Start & Right side of vehicle & Right Side & Either side of vehicle & 0 & 10 \\
\hline 2 & Right side of vehicle & Right side of vehicle & Left Side & Either side of vehicle & 68.615629 & 20.02058469 \\
\hline 5 & Left side of vehicle & Left side of vehicle & Left Side & Either side of vehicle & 302.164802 & 30.11123413 \\
\hline 3 & Right side of vehicle & Left side of vehicle & Left Side & Either side of vehicle & 228.640228 & 40.1798262 \\
\hline 4 & Left side of vehicle & Right side of vehicle & Right Side & Either side of vehicle & 275.479066 & 50.26246992 \\
\hline 6 & Right side of vehicle & Right side of vehicle & Right Side & Either side of vehicle & 500.459645 & 60.41260781 \\
\hline 7 & Left side of vehicle & Right side of vehicle & Left Side & Either side of vehicle & 625.81066 & 70.60035101 \\
\hline 11 & Right side of vehicle & Right side of vehicle & Right Side & Either side of vehicle & 1148.971754 & 80.94504254 \\
\hline 12 & Right side of vehicle & Left side of vehicle & Left Side & Either side of vehicle & 1213.49407 & 91.30909076 \\
\hline 57 & Right side of vehicle & Left side of vehicle & Right Side & Either side of vehicle & 4831.262643 & 102.7584695 \\
\hline 13 & Left side of vehicle & Left side of vehicle & Left Side & Either side of vehicle & 1276.444737 & 113.141403 \\
\hline 14 & Left side of vehicle & Left side of vehicle & Left Side & Either side of vehicle & 1305.64708 & 123.5330971 \\
\hline 15 & Left side of vehicle & Left side of vehicle & Left Side & Either side of vehicle & 1331.707981 & 133.9326095 \\
\hline 8 & Right side of vehicle & Left side of vehicle & Left Side & Either side of vehicle & 800.802215 & 144.1728502 \\
\hline 16 & Right side of vehicle & Right side of vehicle & Right Side & Either side of vehicle & 1381.467183 & 154.5872903 \\
\hline 17 & Left side of vehicle & Left side of vehicle & Left Side & Either side of vehicle & 1430.275527 & 165.016373 \\
\hline 9 & Left side of vehicle & Right side of vehicle & Right Side & Either side of vehicle & 938.094022 & 175.2978012 \\
\hline 10 & Left side of vehicle & Left side of vehicle & Right Side & Either side of vehicle & 992.209234 & 185.5954639 \\
\hline 18 & Right side of vehicle & Left side of vehicle & Left Side & Either side of vehicle & 1504.023731 & 196.0466711 \\
\hline 39 & Left side of vehicle & Left side of vehicle & Right Side & Either side of vehicle & 3174.889471 & 206.9991379 \\
\hline 19 & Right side of vehicle & Right side of vehicle & Left Side & Either side of vehicle & 1580.177136 & 217.473191 \\
\hline 38 & Left side of vehicle & Left side of vehicle & Left Side & Either side of vehicle & 3046.691898 & 228.3871986 \\
\hline 36 & Left side of vehicle & Right side of vehicle & Right Side & Either side of vehicle & 2718.550717 & 239.2027638 \\
\hline 35 & Right side of vehicle & Right side of vehicle & Left Side & Either side of vehicle & 2671.321416 & 250.0041603 \\
\hline 37 & Right side of vehicle & Left side of vehicle & Left Side & Either side of vehicle & 2883.127802 & 260.8690986 \\
\hline 34 & Right side of vehicle & Right side of vehicle & Right Side & Either side of vehicle & 2600.06286 & 271.6491175 \\
\hline 33 & Right side of vehicle & Left side of vehicle & Left Side & Either side of vehicle & 2523.162559 & 282.4060662 \\
\hline 32 & Left side of vehicle & Right side of vehicle & Right Side & Either side of vehicle & 2447.35166 & 293.1402717 \\
\hline 27 & Right side of vehicle & Left side of vehicle & Right Side & Either side of vehicle & 2135.30922 & 303.7808645 \\
\hline 29 & Left side of vehicle & Right side of vehicle & Right Side & Either side of vehicle & 2262.695121 & 314.459673 \\
\hline 30 & Right side of vehicle & Right side of vehicle & Left Side & Either side of vehicle & 2331.459431 & 325.1591108 \\
\hline 40 & Left side of vehicle & Left side of vehicle & Left Side & Either side of vehicle & 3356.191843 & 336.1659684 \\
\hline 31 & Right side of vehicle & Right side of vehicle & Left Side & Either side of vehicle & 2389.422413 & 346.8827951 \\
\hline 28 & Right side of vehicle & Right side of vehicle & Left Side & Either side of vehicle & 2193.782945 & 357.54093 \\
\hline 41 & Left side of vehicle & Left side of vehicle & Right Side & Either side of vehicle & 3446.01737 & 368.5747352 \\
\hline 42 & Right side of vehicle & Right side of vehicle & Left Side & Either side of vehicle & 3491.425797 & 379.622163 \\
\hline 43 & Right side of vehicle & Right side of vehicle & Left Side & Either side of vehicle & 3532.928943 & 390.6820416 \\
\hline 44 & Left side of vehicle & Right side of vehicle & Left Side & Either side of vehicle & 3581.818794 & 401.7565873 \\
\hline 23 & Right side of vehicle & Left side of vehicle & Left Side & Either side of vehicle & 1863.465625 & 412.315627 \\
\hline 45 & Left side of vehicle & Left side of vehicle & Right Side & Either side of vehicle & 3632.193162 & 423.4052849 \\
\hline 21 & Right side of vehicle & Right side of vehicle & Right Side & Either side of vehicle & 1693.602973 & 433.9133658 \\
\hline 46 & Right side of vehicle & Right side of vehicle & Left Side & Either side of vehicle & 3735.450002 & 445.0340008 \\
\hline 22 & Left side of vehicle & Left side of vehicle & Left Side & Either side of vehicle & 1793.080928 & 455.5719251 \\
\hline 49 & Left side of vehicle & Left side of vehicle & Left Side & Either side of vehicle & 3913.937183 & 466.7461062 \\
\hline 48 & Left side of vehicle & Left side of vehicle & Right Side & Either side of vehicle & 3858.28401 & 477.9035914 \\
\hline 47 & Left side of vehicle & Right side of vehicle & Right Side & Either side of vehicle & 3796.373802 & 489.0425036 \\
\hline 20 & Right side of vehicle & Right side of vehicle & Right Side & Either side of vehicle & 1644.460222 & 499.5358417 \\
\hline 26 & Right side of vehicle & Right side of vehicle & Right Side & Either side of vehicle & 2087.970385 & 510.1622328 \\
\hline 25 & Left side of vehicle & Right side of vehicle & Right Side & Either side of vehicle & 2025.884243 & 520.769998 \\
\hline 24 & Right side of vehicle & Right side of vehicle & Right Side & Either side of vehicle & 1992.295259 & 531.3676866 \\
\hline 54 & Left side of vehicle & Right side of vehicle & Right Side & Either side of vehicle & 4382.673756 & 542.6824887 \\
\hline 53 & Right side of vehicle & Left side of vehicle & Left Side & Either side of vehicle & 4329.539208 & 553.9813505 \\
\hline 55 & Left side of vehicle & Left side of vehicle & Left Side & Either side of vehicle & 4491.361497 & 565.328759 \\
\hline 56 & Left side of vehicle & Left side of vehicle & Left Side & Either side of vehicle & 4545.551367 & 576.6924244 \\
\hline 51 & Right side of vehicle & Right side of vehicle & Right Side & Either side of vehicle & 4060.514969 & 587.9105789 \\
\hline 52 & Left side of vehicle & Left side of vehicle & Right Side & Either side of vehicle & 4202.447605 & 599.1713131 \\
\hline 50 & Left side of vehicle & Right side of vehicle & Left Side & Either side of vehicle & 3948.472803 & 610.355855 \\
\hline 58 & Left side of vehicle & End & Right Side & Either side of vehicle & 4959.696504 & 621.8437639 \\
\hline
\end{tabular}




\section{CONCLUSIONS}

1. The destroyed area is estimated for about $\left(0.179 \mathrm{~km}^{2}\right)$ out of the total area of the Nabi-Jarjis district $\left(0.252 \mathrm{~km}^{2}\right)$, or about $71.01 \%$.

2. According to land use, most of the rubble in the Nabi-Jarjis district belongs to the residential buildings, which accounted for about $81.99 \%$ of the total volume of the debris.

3. The total distance for the proposed route for each trip is estimated at 4959.69 meters, according to this, the total time required to collect debris from the study area in each trip is estimated at 621.84 seconds.

4. Debris removal process with the usage of a specific route within viable roads will allow road maintenance operations to be carried out simultaneously with debris removal.

5. The process of removing debris from the Nabi-Jarjis district has begun in an unplanned manner, burying large quantities in low lands near Mosul boundaries which may exacerbate many future risks such as floods. In such cases, today's solution will be the problem of tomorrow.

6. The lack of an appropriate debris management plan leads to the mixing of rubble (mostly concrete, stone and minerals) with other types of waste, including hazardous materials which reduces the chances of recycling the rubble, and here comes the role of finding the optimal route to remove the debris of the Nabi-Jarjis district as an effective planning tool minimizing collection time, distance travelled, and consequently financial and environmental costs for the proposed collection system.

\section{ACKNOWLEDGMENTS}

The authors are very grateful to the University of Mosul / College of Environment Science and Technology for their provided facilities, which helped to improve the quality of this work.

\section{REFERENCES}

Al-Ahmady, k.k. and Jasim, S.D, 2019. Planning the optimal debris removal in large urban centers using GIS / Study case: Souq Almosul in the Old City. Journal of the collage of basic education, Al-Mustansiriyah university, 25(103): 115-135.

Altuhafi, M., Aljameel, S., and Alruzu, Q., 2013. Social and Economic Survey of the Old City of Mosul in 2013, unpublished report for Mosul Municipality.

Ansari, M., Pakrou, S., Abdoli, M.A. and Karbasi, A., 2015.Optimization of MSW Collection Routes Using GIS (Case Study: Tabriz City). Journal of Environmental Science, 10(1): 882-890. 
Asari, M., Sakai, S.I., Yoshioka, T., Tojo, Y., Tasaki, T., Takigami, H. and Watanabe, K., 2013. Strategy for separation and treatment of disaster waste: a manual for earthquake and tsunami disaster waste management in Japan. Journal of Material Cycles and Waste Management, 15(3): 290-299.

Chalkias, C. and Lasaridi, K., 2009. A GIS based model for the optimisation of municipal solid waste collection: the case study of Nikea, Athens, Greece. Journal of technology, 1:11-15.

Greswell, K., 1997. A short Account of Early Muslim Architecture". First edition, Great Britain.

Khoury, D.R., 2002. State and provincial society in the Ottoman Empire: Mosul, 1540-1834. Cambridge University Press.

Mahmood, K.H., 2015. Housing Architecture in Mosul during Ottman Period in 18th and 19th centuries. PhD thesis. Mosul, University of Mosul.,63-72.

Mosul Municipality, 2018. Mosul debris management, unreleased report for the Municipality of Mosul.

O'leary, P.R., Tchobanoglous, G., and Kreith, F., 2002. Handbook of solid waste management, McGraw-Hill: New York.

Parker, M., 2007. Planning Land Information Technology Research Project: Efficient Recycling Collection Routing in Pictou County. Technical report. Available at: http://www.cogs.ns .a/planning /projects /plt 20014/images/research.pdf.

United Nations Environment Programme (UNEP), 2017. Environmental Issues in Areas Retaken from ISIL: Mosul, Iraq, Technical report. Available at: http://www.uniraq.org/index.php?option=com _k2 \&view $=$ item\&task $=$ download\&id=2449 a2a71 fec80f71 cbbe0f3cd5740ccb4ad\&lang=en.

United Nations Environment Programme (UNEP), 2018. Mosul Debris Management Assessment, Technical report, In Proceedings of the Multi stakeholder city wide debris management master plan initiated in Mosul. 